\title{
Ethnic Diversity and Access to Healthcare from a Human Rights Perspective: The Case of the Roma in Europe
}

\author{
Elisavet Athanasia Alexiadou \\ Lawyer, Supreme Court, Greece; Fellow, Global Health Law Groningen Research \\ Centre, Law Faculty, University of Groningen, The Netherlands \\ ea.alexiadou@gmail.com
}

\begin{abstract}
Roma, the largest and oldest ethnic group in Europe, systematically encounter difficulties in healthcare settings, while they are often exposed to high levels of poverty and social exclusion, adversely affecting their health and well-being. In light of this disturbing situation, this paper sets out to examine Roma access to healthcare in Europe from a human rights perspective. This will be followed by an assessment of the status of the Roma right to health (care) within a particular national reality (resource constraints and rising health inequalities). In fact, this case study tends to serve as a piece of discussion about issues relating to Roma access to healthcare, many of which exist (to some extent) in every country across Europe. Finally, practical recommendations are proposed as a way for remedying human rights abuses against Roma in healthcare settings and ultimately, for effectively realizing the Roma right to health (care).
\end{abstract}

\section{Keywords}

Roma - ethnic origin - Europe - right to health (care) - human rights - health inequalities - accountability - participation

Generally, it is acknowledged that the Roma with a long-standing history within Europe have originated in north/north-western India and migrated to 
Europe between the 9th and 14th centuries. ${ }^{1}$ Admittedly, an estimated 10 to 12 million Roma - of whom around half live in the European Union (EU) and are EU citizens (1.18\% of the total EU population) - represent the oldest and largest ethnic group in Europe. ${ }^{2}$ The Roma in Europe constitute a heterogeneous community, which pursuant to the Council of Europe (CoE) and the European Commission encompasses diverse sub-groups, such as Roma, Sinti, Kale, Boyash, Gypsies/Travellers and Eastern groups (Dom and Lom). ${ }^{3}$ For centuries, however, Roma in Europe have been subjected to systematic prejudice and have suffered most from multiple persecution and stigma, with longlasting detrimental effects on their health and well-being. ${ }^{4}$ Nowadays, despite worthwhile efforts of non-governmental and intergovernmental organizations at a policy level, the deep-rooted societal prejudices perpetuate Roma segregation from mainstream society and impede progress, inter alia, in the field of Roma health (e.g., increased illness, low vaccination rates). ${ }^{5}$ Perhaps in recognition of this reality, in 2011, the European Commission when adopting the 'EU Framework for National Roma Integration Strategies up to 2020', recommended all Eu Member States to develop or revise national Roma integration strategies in an effort to ensure effective and concrete results for Roma especially in relation to four crucial areas, inter alia, access to healthcare. ${ }^{6}$ Meanwhile, in its 2016 assessment report, the European Commission critically noted that health

1 I. Mendizabal, O. Lao et al., 'Reconstructing the Population History of the European Romani from Genome-wide Data', Current Biology 22(24) (2012) 2342-2349; Council of Europe, Descriptive Glossary of Terms Relating to Roma Issues (Strasbourg: Council of Europe, 2012), pp. 3-10; I. Hancock, We Are the Romani People (Ame sam e Rromane džene) (Hatfield: University of Hertfordshire Press, 2002) pp. xix-xx, 67-68 and 70.

2 Parliamentary Assembly of Council of Europe, Resolution 1740 on the situation of Roma in Europe and relevant activities of the Council of Europe (2010), para. 1; European Commission's website, 'EU and Roma', http://ec.europa.eu/justice/discrimination/roma/index_en.htm, retrieved 20 February 2017.

3 Supra notes 1 and 2.

4 Hancock, supra note 1, pp. 53-63; see also, Council of Europe Commissioner for Human Rights, 'European history of repression of the Roma', in: Human Rights in Europe: No Grounds for Complacency (Strasbourg: Council of Europe Publishing, 2011) pp. 58-61; European Roma Rights Center, The Limits of Solidarity: Roma in Poland after 1989, Country Report Series No. 11 (Budapest: ERRC, 2002); Hancock, ibid.

5 See in relation, Amnesty international, Human Rights on the Margins - Roma in Europe (London: The Human Rights Action Centre) p. 10; Council of the European Union, Council Recommendation of 9 December 2013 on Effective Roma Integration Measures in the Member States, OJ 2013/C 378/01, 24.12.2013.

6 European Commission, Communication from the Commission to the European Parliament, the Council, the European Economic and Social Committee and the Committee of the 
inequalities experienced by Roma still remain an ongoing challenge, while tailored approaches are needed 'to ensure that mainstream interventions effectively reach out to Roma', such as Roma participation in health and social care initiatives. $^{7}$

In this context, this paper sets out to examine the position of the Roma in Europe in relation to their access to healthcare from a human rights perspective: ${ }^{8}$ (i) by paying attention to principal human rights standards that frame state obligations concerning Roma access to healthcare, (ii) by revealing the human rights abuses against Roma in healthcare settings, and (iii) by assessing the status of the Roma right to health (care) within a particular national reality. In fact, this case study is intended to serve as a piece of discussion about issues related to Roma access to healthcare, many of which exist (to some extent) in every country across Europe. But first, the challenges that impede Roma access healthcare across Europe will be addressed as background information for the subsequent analysis and discussion.

\section{Challenges to Roma Access to Healthcare across Europe}

The starting point for the discussion of the challenges related to Roma access to healthcare across Europe is the widespread recognition among EU Member States and civil society organizations that the Roma in Europe continue to be disproportionally at risk of an array of negative health outcomes. ${ }^{9}$ The Roma are among the most vulnerable and marginalised groups in Europe and experience higher rates of mortality (especially infant mortality) and increased illness (prevalence of communicable diseases, malnutrition) relative to majority

Regions: An EU Framework for National Roma Integration Strategies up to 2020. Сом (2011) 173 final (Brussels, 2011).

7 European Commission, Assessing the implementation of the EU Framework for National Roma Integration Strategies and the Council Recommendation on effective Roma integration measures in the Member States - 2016 сом (2016) 424 final, pp. 7 and 11.

8 Of note, we use the term 'Roma' (the plural for the term 'Rom', a singular masculine noun, meaning 'man' in the language of the Roma) instead of 'Gypsies' or 'Tsigani' (commonly used as an ethnic/racial slur for the Roma), as an umbrella term to refer to people of Roma ethnic origin (see, supra notes 1-2). The latter are not preferable terms, as they often have a negative connotation, namely a pejorative meaning is attached to them by equating all persons of Roma ethnic origin to criminals and uneducated.

9 Supra note 5; European Commission, Roma Health Report - Health status of the Roma population - Data collection in the Member States of the European Union (Brussels: European Union, 2014). 
(non-Roma) population groups in the same region and socioeconomic status. ${ }^{10}$ Indeed, the World Health Organization (wHO) acknowledges that the Roma in Europe are 'vulnerable to ill-health.'11

Undeniably, the precariousness of life conditions which most Roma in Europe experience have serious consequences for their health and human rights more generally. As is well documented, poverty and unemployment among Roma intersect with their access to healthcare across Europe, given that the lack of financial means for transport and healthcare (user) fees (e.g., high prices in medicines) constitute significant barriers for the Roma when seeking care. ${ }^{12}$ At the same time, lack of birth registration and of identity documents further impede Roma from accessing public services, including healthcare. ${ }^{13}$ Similar concerns arise often in relation to housing matters, especially as regards to the dire housing conditions of Roma and the geographical location of Roma settlements (i.e., in remote/rural areas). ${ }^{14}$ For example, a 2016 nine-country survey conducted by the EU Fundamental Rights Agency (EU-MIDIS II), an independent body funded by the European Union, found that $80 \%$ of the Roma surveyed continue to live below the at-risk-of-poverty threshold of their country, with employment rates below the EU average. ${ }^{15}$ Additionally, approximately one in two Roma surveyed (41\%) felt discriminated against due to their ethnic origin at least once in one of the areas of daily life, such as at work, in education, and in healthcare, within the past five years. ${ }^{16}$

Meanwhile, the vulnerability of the Roma has been established and used as a foundation of cases brought before the European Court of Human Rights (ECtHR) and the European Committee of Social Rights (ECSR). Indeed, both

$10 \quad I b i d$; wHO Regional Office for Europe, Improving the health of Roma in the wHo European region: A new initiative of the WHO Regional Office for Europe (Copenhagen: WHO, 2012).

11 Ibid.

12 Supra notes 9 and 11; See also, e.g., European Commission, Report on the implementation of the EU Framework for National Roma Integration Strategies - COM(2014) 209 final, pp. 9-10.

13 Ibid;; See generally, UNICEF, Birth Registration - Right from the Start (Italy: UNICEF Innocenti Research Centre, 2002).

14 Ibid.; European Union Agency for Fundamental Rights (FRA), Housing Conditions of Roma and Travellers in the European Union - Comparative Report (Vienna: FRA, 2009); European Union Agency for Fundamental Rights and UNDP, The Situation of Roma in 11 EU Member States: Survey Results at a Glance (Luxembourg: European Commission Publications Office, 2012).

15 European Union Agency for Fundamental Rights (FRA), Second European Union Minorities and Discrimination Survey: Roma - Selected findings (Luxembourg: Publications Office of the European Union, 2016) pp. 9-10 and 14.

16 Ibid., p. 11. 
adjudicatory bodies have affirmed in their case law that the Roma constitute a vulnerable group in need of special protection and consideration. ${ }^{17}$ In fact, they have considered Roma vulnerable on account of a number of interacting issues/criteria, involving: (i) group's minority/ethnic status (e.g., Chapman v. the United Kingdom (2001)); (ii) historical prejudice and stigmatization against the Roma (e.g., Oršuš and Others v. Croatia (2010)); and (iii) the daily reality for many Roma across Europe - a reality that is largely characterized by the precariousness of life conditions (e.g. Complaint No. 61/2010). ${ }^{18}$

At the same time, at a policy level, (societal) prejudices against the Roma in Europe and ensuing Roma rights challenges have informed a significant proportion of the Council of Europe ( $\mathrm{CoE}$ ) activities which are targeted towards the social inclusion of the Roma across Europe. Clearly, for over three decades, the situation of the Roma in Europe has been an issue of policy concern at the CoE level. For example, in its 563 recommendation, the parliamentary assembly addressed the situation of Roma in Europe by placing its focus on their particular vulnerability on account of their ethnic origin. ${ }^{19}$ In recent years, on 20 October 2010 the CoE, when issued the 'Strasbourg Declaration on Roma', reaffirmed its past position, after noting that the ongoing social and economic marginalization of the Roma in Europe 'undermines the respect of their human rights', and stressed the importance of Roma effective participation in the process of positive changes, geared towards tackling Roma rights challenges and towards improving Roma integration and empowerment across Europe. ${ }^{20}$

17 ECtHR, Chapman v. the United Kingdom, Application no. 27238/95, 18 January 2001, para. 96; ECtHR, Oršuš and others v. Croatia, Application no. 15766/03, 16 March 2010, paras. 147-148 and 182; See generally, the following ECtHR cases in relation to Roma treatment and Roma identity: for example, Beard v. the United Kingdom (Application no. 24882/94, 18 January 2001); Coster v. the United Kingdom (Application no. 24876/94, 18 January 2001); Jane Smith v. the United Kingdom (Application no. 25154/94, 18 January 2001); Lee v. the United Kingdom (Application no. 25289/94, 18 January 2001); See, e.g., ECSR, European Roma Rights Centre (ERRC) v. Portugal, Complaint No. 61/2010, decision on the merits of 30 June 2011, para. 20.

18 Ibid.

19 Parliamentary Assembly, Recommendation 563 (1969) on 'the Situation of Gypsies and other travellers in Europe', 30 September 1969.

20 Council of Europe, The Strasbourg Declaration on Roma, adopted on 20 October 2010 at the Council of Europe High Level Meeting on Roma in Strasbourg, CM (2010) 133 final, paras. (1) et seq. 
The challenges obstructing Roma access to healthcare contrast with the very nature of human rights law on the basis of which each individual possesses an inherent dignity as well as an entitlement to all human rights. Roma in Europe face disproportionate barriers which go to the heart of realizing their right to health (care) in that they often experience disparities in accessing healthcare and in health outcomes. Generally, since the adoption of the first right to health provision in the 1946 wHO's constitution, health as a human right has been firmly enshrined and elaborated in a number of subsequent human rights instruments at the international and regional levels. ${ }^{21}$ Most notably, the International Covenant on Economic, Social and Cultural Rights (ICESCR), the first international legal source that recognizes ESC rights, proscribes any discrimination as to race, national or social origin or other status in the exercise of the right to health under its Article 12 read together with its Article 2(2).22 Additionally, the International Convention on the Elimination of all forms of Racial Discrimination (ICERD) in Article 5(e)(iv) underlines the state responsibility to prohibit and eliminate racial discrimination in the enjoyment of the right to public health, medical care, social security and social services. ${ }^{23}$ Aside from the treaties, un treaty monitoring bodies have also drawn attention to the elimination of any form of discrimination in access to healthcare 'on the grounds of race, ..., national or social origin ....24 The Committee on Economic, Social and Cultural Rights (CESCR) has explicitly stressed in its General Comment No. 14 that states parties have a duty to respect the right to health by ensuring that all persons have equal access to preventive, curative and palliative health services and by abstaining from imposing discriminatory practices as a state policy [emphasis added]. ${ }^{25}$ In fact, considering that ethnic groups, like Roma, live often in geographically isolated or remote areas (see above section 2), the CESCR has particularly emphasized that health services

21 Constitution of the World Health Organization, Un Doc. E/155 (1946), preamble.

22 International Covenant on Economic, Social and Cultural Rights (ICESCR), G.A. Res. 2200A (XXI) (1966).

23 International Convention on the Elimination of All Forms of Racial Discrimination (ICERD), G.A. Res. 2106 (xx) (1965).

24 UN Committee on Economic, Social and Cultural Rights (CESCR), General Comment No. 14: The Right to the Highest Attainable Standard of Health, UN Doc. E/C.12/2000/4 (2000), para. 18.

Ibid., para. 34 . 
must be provided in 'safe physical reach' for all sections of the population, especially for vulnerable or marginalised groups, like ethnic minorities; while at the same time these services must be culturally appropriate. ${ }^{26}$ Meanwhile, the Committee on the Elimination of Racial Discrimination (CERD) goes even further by drawing the attention of the states, in particular, to take measures to eliminate discrimination against Roma, inter alia, in their access to healthcare services, ranging from the provision of equal access to healthcare and social security services to areas involving the design and implementation of health programmes targeted to Roma children and women. ${ }^{27}$

At the regional, $\mathrm{CoE}$ level, by embracing a non-discrimination clause in Article E, the (Revised) European Social Charter (ESC) prohibits all forms of discrimination in relation, inter alia, to the right to protection of health (Article 11), and to the right to social and medical assistance (Article 13). ${ }^{28}$ At the same time, the Biomedicine Convention and its explanatory report give substantive meaning to the right to equitable access to healthcare recognised in its Article 3 by requiring states to provide healthcare of appropriate quality, targeted to a person's medical needs and with the absence of unjustified discrimination. ${ }^{29}$ Meanwhile, at Eu level, the Charter of Fundamental Rights of the EU in Article 21 prohibits discrimination on grounds of racial or ethnic origin, while the Council Directive 2000/43/EC specifies that Member States shall combat discrimination on these grounds, inter alia, in the area of social protection, involving social security and healthcare as well as in access to and supply of goods and services, available to the public. ${ }^{30}$

All in all, these (human rights) instruments call for a state focus on the elimination of health inequalities on grounds involving racial or ethnic origin in

\footnotetext{
$26 \quad$ Ibid., para. 12(b) and (c).

27 UN Committee on the Elimination of Racial Discrimination (CERD), General Recommendation No. 27: Discrimination against Roma, un Doc. A/55/18 (2000), paras. $3^{1}$ and 33-34.

28 European Social Charter (ESC, 1961), ETS No. 35; Revised European Social Charter (RESC, 1996), ETS No. 163 .

29 Convention for the Protection of Human Rights and Dignity of the Human Being with regard to the Application of Biology and Medicine: Convention on Human Rights and Biomedicine (1997), CETS No. 164; Explanatory Report to the Convention on Human Rights and Biomedicine (2009), paras. 23-25.

30 Charter of Fundamental Rights of the European Union, OJ 2000/C 364/o1; Article 3(1)(e) and (h). Council of the European Union, Directive 2000/43/EC of 29 June 2000 implementing the principle of equal treatment between persons irrespective of racial or ethnic origin, OJ L180, 19.7.200o, pp. 22-26.
} 
the formulation of national health-related law and policies; as such, these instruments provide a principal foundation for securing an unimpeded Roma access to quality healthcare.

As already noted, instead of unimpeded access to quality healthcare, many Roma often encounter a number of abuses (e.g., ranging from violations to their rights to informed consent and non-discrimination to cruel, inhuman and degrading treatment), that affront their dignity and have detrimental effects on their health. The following section demonstrates the potential of particular (quasi)-judicial bodies of the CoE - the ECSR and the ECtHR - to play a role in the implementation process in terms of reviewing law, policies and practices relating to the access and delivery of healthcare services for the Roma in Europe. In addition, the examination of respective case law of these bodies captures the (potential) anti-Roma discrimination and the (social) exclusion of the Roma in Europe, ranging from the denial of access to healthcare or access to substandard care, to the forced sterilization of Roma women. In this regard, the case law of these two bodies will be examined through an exemplary analysis of particular landmark cases relating to Roma access to healthcare in Europe.

\subsection{European Committee of Social Rights}

In virtue of the Additional Protocol to the (Revised) EsC, the ECSR is entitled to examine collective complaints - lodged by defined organizations, including trade unions and non-governmental organizations - and to conclude with a (non-binding) decision concerning the state compliance with obligations imposed by the Charter. ${ }^{31}$ Hitherto, the ECSR - the body responsible for monitoring the application of the Charter - reviewed Roma access to healthcare under the system of collective complaints in four cases. ${ }^{32}$

The first case was the case of Complaint No. 46/2007, lodged by the European Roma Rights Center (ERRC) against Bulgaria. ${ }^{33}$ In this Complaint, the

31 Articles 1-2, 5 and 8(1) Additional Protocol to the European Social Charter Providing for a System of Collective Complaints, ETs No. 158, adopted on 9 November 1995, entered into force on 1 July 1998; Article 25 (Revised) ESC.

32 Ibid.; up until 10 June 2017.

33 ECSR, European Roma Rights Centre (ERRC) v. Bulgaria (2008) (complaint no. 46/2007), Decision on the merits. 
ECSR noted that Roma communities in Bulgaria encountered disproportionate health risks partly owed to the failure of state prevention policies and as a result, their health status was 'inferior to that of the general population' [emphasis added]. ${ }^{34}$ At the same time, the Committee found that the Bulgarian health insurance legislation did not ensure universal access to health insurance coverage and as such, Roma, who either did not receive social assistance or had temporarily lost their right to social assistance, were left without healthcare coverage. ${ }^{35}$ The ECSR therefore concluded that the state's failure to meet its positive obligations to ensure that Roma enjoy an adequate access to healthcare constituted a violation of Article 11 (right to health) in conjunction with Article E (non-discrimination) and of Article $13 \$ 1$ (right to social and medical assistance) of the (Revised) ESC. ${ }^{36}$ In 2009, the ECSR took a similar approach in the case of Complaint No. 48/2008, which was brought again by the European Roma Rights Center (ERRC) against Bulgaria. ${ }^{37}$ The ECSR found a violation of Article $13 \S 1$ (right to social and medical assistance) of the (Revised) EsC on account of the state's failure to ensure for the unemployed and especially for the Roma adequate access to social and medical assistance (healthcare coverage), in virtue of the amendments to the Bulgarian Social Assistance Act by using a similar line of reasoning to that of Complaint No. 46/2007. ${ }^{38}$ However, and somewhat paradoxically, the Committee, despite acknowledging the particular disadvantaged status of the Roma in Bulgaria (e.g., impediments to access the labour market), did not examine the allegations of a breach of Article E (non-discrimination) in conjunction with Article $13 \S 1$ (right to social and medical assistance) of the (Revised) Esc. ${ }^{39}$ For the Committee, simply such allegations were 'subsumed ... within the wider question' of whether the legislative amendments in question were in breach of Article $13 \S 1 .{ }^{40}$ In this case, it seems that the Committee tends to overlook the overall context of prejudice and discrimination within which the Roma are situated. This might explain C. Kollonay Lehoczky's reaction in her dissenting opinion, stressing that, given the historic discrimination against Roma, the denial by the majority to distinguish the effect of the amendments to the Bulgarian Social Assistance

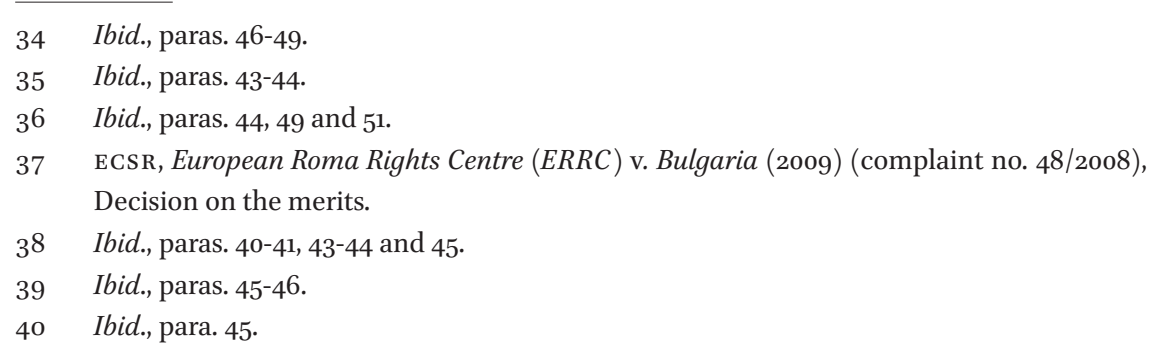


Act between the Roma and the non-Roma 'denies the concept of indirect discrimination lying, at the minimum, behind the amendment of the Bulgarian Social Assistance Act'.41

Meanwhile, in Médecins du Monde-International v. France, a complaint concerning migrant Roma in France, mainly coming from Romania and Bulgaria, the ECSR explicitly stressed that the healthcare system must be accessible to everyone, especially to disadvantaged groups. ${ }^{42}$ The Committee affirmed that all migrant Roma (in a regular or an irregular situation), had the right to access adequate healthcare, which was not restricted to emergency services. Consequently, the Committee found that the state failed to meet its positive obligations under Article 11 (right to health) in conjunction with Article E (nondiscrimination) towards migrant Roma, irrespective of their residence status, especially as it did not take reasonable steps to address the specific problems faced by Roma communities due to their often unhealthy living conditions and difficult access to health services. ${ }^{43}$ Obviously, by reaching this decision the Committee expanded the Charter's scope of application (i.e., Article 11) as to include non-nationals, namely Roma irregular migrants - albeit aware of the Charter's provision which affords protection to persons - foreigners only in so far as they are nationals of other contracting states lawfully resident or working regularly within the territory of the party concerned. ${ }^{44}$

Recently, in 2016, the ECSR decided another complaint involving Roma access to healthcare, lodged against the Czech Republic, namely the case of $E \mathbf{E}$ ropean Roma and Travellers Forum (ERTF) v. the Czech Republic. ${ }^{45}$ In this case, the ECSR reaffirmed that 'the health care system must be accessible to everyone, especially the healthcare should be available to all who require it, and free of charge to those without the necessary resources' [emphasis added] ${ }^{46}$ By taking this view, the Committee found a breach of Article 11, after also noting that the state measures 'do not sufficiently ensure healthcare for poor or socially

41 Ibid., p. 17.

42 ECsR, Médecins du Monde - International v. France (2013) (complaint no. 67/2011), Decision on the merits, paras. 6 and 139 .

43 Ibid., paras. 144-145, 152-153 and 163-164.

44 (Revised) ESC - Appendix, para. 1. It reads as follows: 'Without prejudice to Article 12, paragraph 4, and Article 13, paragraph 4, the persons covered by Articles 1 to 17 and 20 to 31 include foreigners only in so far as they are nationals of other Parties lawfully resident or working regularly within the territory of the Party concerned, subject to the understanding that these articles are to be interpreted in light of the provisions of Articles 18 and 19'. ECSR, European Roma and Travellers Forum (ERTF) v. the Czech Republic (2016) (complaint no. 104/2014), Decision on the merits.

46 Ibid., para. 117. 
vulnerable persons who become sick, such as Roma who have lost health insurance' and encounter disproportionate health risks. ${ }^{47}$ The Committee therefore concluded that Article 11 (right to health) of the Charter was violated on account of the problems endured by many Roma families in accessing healthcare services, attributed to the state's failure to meet its positive obligations, namely 'to take appropriate measures to address the exclusion and marginalization in the field of health to which Roma communities are exposed', 48

\subsection{European Court of Human Rights}

As is well known, the ECtHR has adjudicated on several health-related issues in its case law under provisions of the European Convention for the Protection of Human Rights and Fundamental Freedoms (ECHR) - albeit the ECHR is essentially concerned with the protection of civil and political rights (e.g., the right to life) and not with economic, social and cultural rights (e.g., the right to health (care)). ${ }^{49}$ Admittedly, the ECtHR has demonstrated its willingness to exercise control over practices relating to Roma women's reproductive health and rights and to redress of violations of the ECHR in four cases on forced sterilization decided between 2009 and 2012. In K. H. and Others v. Slovakia, the applicants, eight female Slovakian nationals of Roma ethnic origin, alleged that they were denied effective access to medical information, by means of making photocopies of their medical records for the purpose: (i) of obtaining a medical analysis of their health status and establishing the reason for their infertility; and (ii) of litigation proceedings in relation to a sterilization procedure to which they were subjected without their knowledge or informed consent, while giving birth by caesarean section, constituted an Article $8 \mathrm{ECHR}$ (right to respect for private and family life) violation and an Article $6 \S 1$ ECHR (access to a court) violation..$^{50}$ Indeed, the Court concluded that there was a violation of Article $8 \mathrm{ECHR}$, after noting that 'the exercise of the right under Article 8 to respect for one's private and family life must be practical and effective' and as

\footnotetext{
47 Ibid., paras. 119-120.

48 Ibid., paras. 127-128.

49 European Convention for the Protection of Human Rights and Fundamental Freedoms, November 4, 1950, 213 U.N.T.S. 221, as amended by Protocol No. 11, November 1, 1998, E.T.S. No. 155; See generally, I. Brownlie and G.S. Goodwin-Gill, Brownlie's Documents on Human Rights (6th ed.), (Oxford: Oxford University Press, 2010) p. 681; A. Hendriks, 'The Council of Europe and Health and Human Rights', in: B. Toebes et al. (eds.), Health and Human Rights in Europe (Antwerp: Intersentia, 2012) pp. 23-50, p. 27.

$50 \quad$ ECtHR, $K$. H. and Others v. Slovakia, Application no. 32881/04, 28 April 2009, paras. 37-38 and $59-60$.
} 
such, access to one's personal data files must be allowed..$^{51}$ At the same time, the Court found a violation of Article $6 \S 1 \mathrm{ECHR}$, maintaining that the restrictions in access to the medical files under section 16(6) of the Health Care Act 1994 'imposed a disproportionate limitation on their ability to present their cases to a court in an effective manner.'52

Obviously, in the $K . H$. and Others judgment the ECtHR did not consider the implications of the systematic aspect of forced sterilization of eight Roma women. However, two years after the $K$. $H$. and Others judgment, the Court took a bold stand vis-à-vis forced sterilization of Roma women in a series of three cases. In V.C. v. Slovakia, the ECtHR attached considerable weight in its reasoning to the manner of the sterilization of the applicant of Roma origin, namely to the sterilization of a mentally competent adult patient without her free and informed consent. The Court, after initially noting that 'sterilization constitutes a major interference with a person's reproductive health status', acknowledged that 'the sterilization procedure grossly interfered with the applicant's physical integrity' and that the medical staff acted 'with gross disregard to her right to autonomy and choice as a patient' by not giving the applicant the time and necessary information about this procedure (i.e., after the consideration of all the implications). ${ }^{53}$ As a consequence of this line of reasoning, the Court concluded that there was a violation of Article 3 ECHR (prohibition of inhuman or degrading treatment). ${ }^{54}$ At the same time, the Court found a violation of Article $8 \mathrm{ECHR}$ (right to respect for private and family life) in virtue of the state's failure to offer effective legal safeguards to protect the reproductive health of the applicant. ${ }^{55}$ Interestingly, albeit it noted the widespread negative attitudes towards Roma, the Court did not examine separately the applicant's alleged violation of Article 14 ECHR (prohibition of discrimination), namely the connection between the (social) prejudices against Roma and the practice of forced sterilization of the applicant of Roma ethnic origin based on the assessment of the facts of the case before it. ${ }^{56}$

$51 \quad$ Ibid., paras. 47 and 58 .

$52 \quad$ Ibid., paras. 67 and 69 .

53 ECtHR, V. C. v. Slovakia, Application no. 18968/07, 8 November 2011, paras. 111-112, 116 and 119.

54 Ibid., para. 120.

55 Ibid., paras. 154-155.

56 Ibid., paras. 146 and 178-180; See in relation, L. Peroni and A. Timmer, 'Vulnerable groups: The promise of an emerging concept in European Human Rights Convention law', I·CON $11(4)(2013) 1056-1085,1066$. 
The ECtHR came to similar conclusions in $N$. B. v. Slovakia, a case concerning the forced sterilization of a Roma woman who was a minor at the time of the medical intervention. ${ }^{57}$ Once again the Court affirmed its position about the serious consequences of the practice of sterilization when its performance is 'incompatible with the requirement of respect for human freedom and dignity', including: (i) disregard for the applicant's (and/or her representative's) prior informed consent; and (ii) the state's failure to ensure sufficient legal safeguards for the applicant's reproductive health. ${ }^{58}$ The Court therefore found violations of both Articles 3 ECHR (prohibition of inhuman or degrading treatment) and 8 ECHR (right to respect for private and family life) on account of the applicant's forced sterilization. ${ }^{59}$ At the same time, like in $V$. C. v. Slovakia judgment (2011), the Court again was reluctant to separately examine the applicant's complaint under Article 14 ECH R (prohibition of discrimination) and assess the practice of forced sterilization of Roma women within the broader context of prejudice against Roma. ${ }^{60}$

In yet another 2012 case, I. G. and Others v. Slovakia, the Court used a similar line of legal reasoning to that issued in the $N$. B. v. Slovakia case and reiterated its approach by finding violations of Articles 3 ECHR (prohibition of inhuman or degrading treatment) and $8 \mathrm{ECHR}$ (right to respect for private and family life) on account of the applicants' sterilization without prior informed consent. ${ }^{61}$ Meanwhile, as in the cases of V. C. v. Slovakia (2011) and N. B. v. Slovakia (2012), the Court did not proceed to the separate examination of the applicant's discrimination complaint under Article 14 ECHR (prohibition of discrimination).$^{62}$ Thereto, one could maintain that on account of the Court's tendency not to examine alleged violations of Article 14 ECHR (prohibition of discrimination) in the aforementioned cases, the Court has intended to avoid opening a discussion as to the (negative) impact of prejudices (e.g., indirect discrimination as a minimum) against the Roma in Europe in the field of health (in this cases).

The cases brought before the ECSR and the ECtHR concerning Roma access to healthcare constitute the tip of an iceberg, mostly revealing the ongoing substandard treatment of the Roma in Europe while at the same time

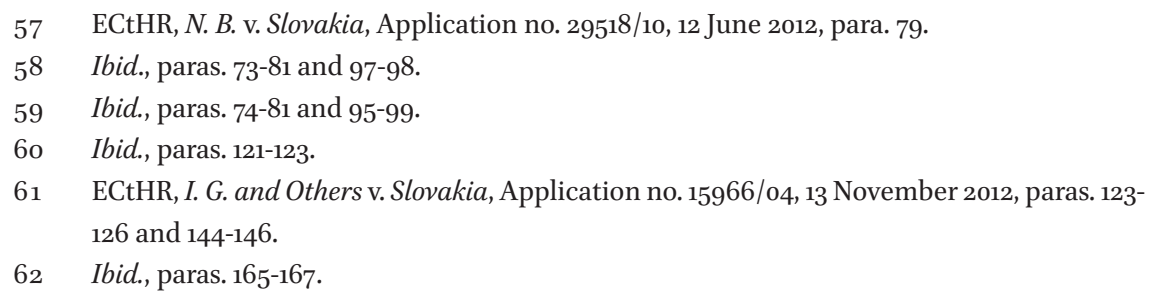


presenting enduring and pressing Roma rights challenges that need to be effectively addressed by the European states.

\section{A Case Example: Evaluating Roma Access to Healthcare in Greece}

For years, Roma in Greece remain marginalized from many aspects of daily (social) life associated with (persistent) discrimination that they encounter in the fields of healthcare, housing, education and employment. ${ }^{63}$ Roma in Greece are largely characterized by high levels of poverty (below the national income), low education and employment rates (unemployment rates 3 times higher than the rest of the population), and poor health. ${ }^{64}$ Particularly, in terms of health outcomes, available data and estimates reveal that in Greece Roma face health inequalities with a lower life expectancy compared to the rest of the population. ${ }^{65}$ This disturbing level of (avoidable) health disparity is largely linked to the poor environmental conditions of Roma (especially exposed to substandard housing conditions), lack of awareness-raising campaigns tailored to the diversity of Roma, limited Roma access to quality (primary) healthcare and consequently, exposure of Roma to higher health risks. ${ }^{66}$ Additionally, the experience of discrimination within healthcare settings ( $18 \%$ of the Roma respondents) hinders Roma access to healthcare and,

63 UN CESCR, Concluding Observations on Greece, UN Doc. E/C.12/1/Add. 97 (2004), para. 11; UN CESCR, Concluding Observations on Greece, UN Doc. E/C.12/GRC/CO/2 (2015), para. 9; UN CERD, Concluding Observations on Greece, UN Doc. CERD/C/GRC/ CO/20-22 (2016), para. 20; Supra note 15, pp. 10-11; See in relation to the situation of Roma children in Greece, E. A. Alexiadou, '8. Roma Children', in: The Right to Health. A Human Rights Perspective with a Case Study on Greece, (Thessaloniki/Athens: University Studio Press, 2016) pp. 249-285.

64 Supra note 15, p. 14; European Union Agency for Fundamental Rights (FRA), Roma SurveyData in Focus: Poverty and Employment: the Situation of Roma in 11 EU Member States (Brussels: Publications Office, 2014) p. 22.

65 Supra note 14, FRA and UNDP 2012, p. 30.

66 Council of Europe, The Council of Europe: Protecting the Rights of Roma (Strasbourg: the Council of Europe's Directorate of Communication in collaboration with the Support Team of the Special Representative of the Secretary General for Roma Issues, September 2011); supra note 63, UN CESCR 2004, paras. 11 and 15; UN CRC Committee, Concluding Observations on Greece, UN Doc. CRC/C/GRC/CO/2-3 (2012), para. 52; UN CRC Committee, Concluding Observations on Greece, UN Doc. CRC/C/15/Add.170 (2002), para. 56(e); un Committee on the Elimination of Discrimination Against Women, Concluding Observations on Greece, UN Doc. CEDAW/C/GRC/CO/7 (2013), para. 32. 
consequently, further weakens their health status. ${ }^{67}$ At the same time, another critical issue is that given the 7 year lasting economic crisis in Greece (i.e., from 2010 onwards), the Greek state generated a number of (austerity) measures, like the curtailing of public health expenditure, which not only placed an excessive financial burden on the Roma accessibility to healthcare, but also had an adverse impact on the sustainability of policies affecting their lives (see section 5.2). ${ }^{68}$ Thereto, from a human rights perspective such developments raise issues of great concern relative to the increasing health inequalities detected between Roma and non-Roma groups, as previously noted.

In Greece, Roma are estimated to be between 175,000 and 350,000 (almost between $1.55 \%$ and $3.1 \%$ of the total population), while there is no available data on their exact number, inter alia, due to informal settlement. ${ }^{69}$ In addition, despite a long presence of Roma in Greece, it was not until the 1970s that in virtue of the Legislative Decree 3370/1955 the Greek state decided to fully regulate the acquisition of Greek citizenship from the then unregistered Roma residing in Greece. ${ }^{70}$ Here, for the purposes of our examination, the term 'Roma' refers to the group long-term settled within the selected EU Member State and particularly, the Greek Roma and as such, it does not cover other related groups who have migrated from other states.

67 European Union Agency for Fundamental Rights (FRA), EU-MIDIS Data in focus report 1: the Roma (Vienna: FRA, 2009) p. 5; Supra note 63, UN CESCR 2015.

68 Supra note 63, UN CERD (2016), paras. 6-7; See generally, G. Sakkelis, 'Social rights in time of crisis', in: Annual report 2010 Greek Ombudsman - Social Protection (Athens: State printing 2010) p. 57 .

69 European Commission, The European Union and Roma - Factsheet - Greece (Brussels: European Commission, 2014); European Roma Rights Center (ERRC), Submission of the European Roma Rights Centre Concerning Greece for Consideration under the Universal Periodic Review by the United Nations Human Rights Council (HRC) at its 11th Session on May 2-11, 2011, p. 1; Concerning the Roma informal settlement in Greece and Roma lack of awareness (or even negligence) as to the birth registration procedures, see, Parliament of Greece (Period IE' - Synod A'), Official Records of Parliament's Session $\Gamma^{\prime}$ (Athens, 25 July 2013) pp. 47-50.

70 Legislative Decree (LD) 3370/1955, Official Government Gazette-ФEK issue A' 258/2309-1955; Ministry of Interior and Administrative Reconstruction, General Orders 69468/212/20-10-1978 on the 'regulation of the citizenship of the Roma living in Greece' and 16701/51/12-03-1979 on the 'registration of undocumented Roma'. Note that the citizenship of the Muslim Roma of Thrace was regulated in the 1920 (see, LD of 25 August 1923, Official Government Gazette-ФEK issue A' 238). 


\subsection{Greek Legal Context}

Greece is a party to most of the human rights treaties that guarantee a right to health (care) for every individual (for example, the ICESCR, the ICERD, the RESC, and the Biomedicine Convention).$^{71}$ In fact, after ratification, these treaties have been incorporated within the national legal system and as such they can be applied before the Greek courts as well as prevail over any contrary law provision..$^{72}$ Clearly, Greece has undertaken legal obligations relating to the internationally guaranteed right to health. In addition to the treaty provisions, at the constitutional level, there are several provisions of importance that entrench an entitlement to health (care) for Roma communities in Greece. Indeed, the Constitution of Greece (in Greek: Syntagma, henceforth: the Constitution) recognizes a general state obligation to care for the citizens' health in Article $21 \S 3$ as well as an individual right to the health protection in Article $5 \$ 5 .{ }^{73}$ Added to the above provisions, of particular interest is Article $25 \S 1$ of the Constitution stipulating the principle of welfare state and as such this provision provides an expansive protection of every individual's rights, including the Roma right to health (care). Moreover, in virtue of the broadly formulated Article $5 \S 2$ which guarantees the right to life and human dignity to every individual, while at the same time embraces the principle of non-discrimination, a health (care) entitlement - albeit minimum - could also be granted to Roma. Meanwhile, Greek legal order contains also several pieces of legislation generally regulating access to healthcare for (vulnerable) population groups in society, without though exclusively addressing Roma access to health (care). Most importantly, Law 1397/1983 (widely known as the founding law of the Greek National Health System - in Greek: Ethniko Systima Ygeias, ESY) and Law 4238/2014 on primary healthcare constitute notable moves towards health equity, in that they both emphasize the state obligation to provide universal access to healthcare for all citizens, regardless of financial, employment and social status. ${ }^{74}$

71 ICESCR - Law 1532/1985, Official Government Gazette-ФEK issue A' 45/19-03-1985; ICERD - LD 494/1970, Official Government Gazette-ФEK issue A' 77/03-04-1970; RESC Law 4359/2016, Official Government Gazette-ФEK issue A' 5/20-01-2016; Biomedicine Convention-Law 2619/1998, Official Government Gazette-ФEK issue A' 132/19-06-1998.

Ibid.; Article 28, The Constitution of Greece (1975-1986-2001-2008), as revised by the parliamentary resolution of 27 May 2008 of the VIIIth Revisionary Parliament and published in the Official Government Gazette- $\Phi$ EK issue A' 120/27-06-2008.

Ibid.

74 Article 1(2) Law 1397/1983, Official Government Gazette-ФEK issue A' 143/07-10-1983; Article 1(3) Law 4238/2014, Official Government Gazette-ФEK issue A' 38/17-02-2014. 


\subsection{Roma Access to Public Healthcare and the AAAQ}

Seemingly, the Greek state has enacted several pieces of legislation, which facilitate Roma access to public healthcare. However, in reality an unimpeded Roma access to public healthcare in Greece is far from settled. This becomes most obvious when Roma access to public healthcare is evaluated against a significant component of the right to health, namely the AAAQ framework which declares that healthcare services have to be available, accessible, acceptable, and of good quality - as well as against the human rights principles of accountability and participation. ${ }^{75}$

Since 1997, the state has acknowledged the need for designing and implementing health programmes addressed to at high-risk population groups with ethnic, social and cultural differences. ${ }^{76}$ Nonetheless, since 2002 and until the end of 2013, Roma access to healthcare was expressly facilitated through the establishment of 35 centres (former Medico-Social centres) operating locally, in Roma authorized settlements (in most cases on the outskirts of large cities, such as Athens). ${ }^{77}$ The provided services under this temporary infrastructure included: counselling; provision of basic health services; children vaccination; health education; support in the process for acquiring adequate housing; registration; and monitoring of Roma needs for planning further policy actions towards social inclusion. ${ }^{78}$ Recently (in March 2016), perhaps in view of the ongoing economic recession, the Greek state decided to reestablish these support centres for Roma and other vulnerable groups. ${ }^{79}$ In practice, however, this state decision still (one year later) remains far away from reaching its target in that the state has not actively engaged with its practical operationalisation. Thereto, in reality it appears that a state decision alone is not sufficient, unless it is accompanied by implementation measures required for its practical

75 Supra note 24, paras. 11 (political participation), 12, 17 (political participation), 34, 54, 55 and 59 (legal accountability).

76 Article 3(3)(c), Law 2519/1997, Official Government Gazette-ФEK issue A' 165/21-08-1997.

77 As to the establishment, and implementation procedure of the then Medico-Social Centers, see, Joint Ministerial Decision No. 113956/02-10-2002, Official Government Gazette-ФEK issue B', 1295/04-10-2002; Joint Ministerial Decision 1.5422/oik.31022/0205-2011, Official Government Gazette-ФEK issue B' 824/12-05-2011 on 'System for the Management, Evaluation, Control and Procedure for the Implementation of Action Centers for the Support of Roma and Other Vulnerable Groups - in terms of the National Strategic Framework for the Period 2007-2013'.

78 Ibid.; ECSR, Conclusions XIX-2 (2009) on Greece, p. 11.

79 Joint Ministerial Decision D23/OIK.14435-1135/2016, Official Government Gazette-ФEK issue $B^{\prime}, 854 / 30-03-2016$ on the determination of the minimum operational requirements of the Community Centers. 
operationalisation - including budgetary and administrative measures-. Indeed, over the years, it seems that the Greek state has tended to launch several fragmented policies in relation to Roma, without careful planning (for example, without developing a proper health infrastructure - a community-based primary healthcare - especially in very remote and rural areas). Evidence of this can be found in the reports of the Hellenic Centre for Disease Control and Prevention (HCDCP, abbreviated in Greek as KEELPNO), pursuant to which since 2013 a high prevalence of Hepatitis A Virus (HAV - a vaccine preventable disease) was detected in Roma camps in the regions of northern Greece (i.e., north-western Greece and Thrace province), while new incidents were reported also in 2014. ${ }^{80}$ Such outbreaks largely uncover the poor implementation (or even a lack) of preventive programmes in rural and remote areas of Greece (for example, lack of coordinated and well-resourced immunization programmes), which gives rise to the added problem of disparities in physical accessibility in relation to Roma residing in areas with a low population density (see below). ${ }^{81}$ In their reviews of Greece's reports the CESCR and the Committee on the Rights of the Child (CRC Committee) have both emphasized the state's duty to meet the demands in medical treatment, especially in relation to the needs of disadvantaged and marginalised members of the population, like Roma. ${ }^{82}$

Another issue of high concern is accessible healthcare without discrimination, one of the elements of accessibility under the AAAQ. ${ }^{83}$ It requires special attention that several human rights monitoring bodies, like the CESCR, the CERD and the CRC Committee, have hinted at the state's failure to remove discrimination against Roma in their reports for Greece where they expressly noted their concern about the negative attitudes, prejudices and persistent discrimination against Roma particularly in healthcare. ${ }^{84}$ Such a situation creates tension also with the criterion of (cultural) acceptability of healthcare services. In fact, this could be a disturbing development in that in principle the state has enacted an anti-discrimination framework, namely Law 3304/2005 and Law 4443/2016, pursuant to the Council Directive 2000/43/EC, in relation,

8o K. Mellou and T. Sideroglou (Hellenic Centre for Disease Control and Prevention), 'Increased number of hepatitis A reported cases among Roma in 2013 and January 2014, Greece', e-bulletin-HCDCP-Ministry of Health 35 (2014) 9-10.

81 Supra note 9, European Commission, 2014, p. 43.

82 Supra note 63, UN CESCR 2015, paras. 35-36; supra note 66, UN CRC Committee 2012, paras. 53 and 72 (b); supra note 66, UN CRC Committee 2002, para. 56 .

$83 \quad$ Supra note 24, para. 12 (b).

84 Supra note 63, UN CESCR 2015, para. 9; supra note 63, UN CERD 2016, para. 20; supra note 66, UN CRC Committee 2012, para. 71 . 
inter alia, to social protection, including healthcare. ${ }^{85}$ Furthermore, especially from 2010 onwards the increasing demands on payments associated with the high rates of poverty and unemployment among Roma put a strong pressure on the affordability of healthcare. ${ }^{86}$

At the same time, physical (geographic) accessibility of healthcare especially for Roma living in (very) remote and often very impoverished areas is seriously threatened given the distance and travel time to health facilities and services in connection with the absence of convenient and affordable transport. Here, it is essential to note that another critical issue which further impedes physical accessibility is the mergers between hospitals and other healthcare facilities (e.g., rehabilitation care units), owed to the dramatic reductions in public health spending from 2010 onwards when Greece was hit by the economic crisis. ${ }^{87}$ Notwithstanding this worrying development, as a response to the European Commission's call on the integration of Roma up to 2020, the Greek state undertook certain activities, inter alia, in the area of Roma accessibility to (primary) healthcare. ${ }^{88}$ In 2012, the HCDCP with its mobile healthcare units (MHUS) delivered its services to Roma temporary sites (primarily outside major city areas and regional areas) based on its overall mandate to promote public health and on the specific tasks assigned to it by the Ministry of Health. ${ }^{89}$ It seemed that such a practice intended not only to promote Roma physical accessibility to (primary) healthcare, but also to absolve Roma from their distrust towards public (health) services and in turn, to promote their social integration..$^{90}$ Nonetheless, this intervention was discontinued after one year of operation, perhaps due to a lack of proper (sustainable) design, involving lack of funding, and the non-participation of Roma - the intended beneficiaries in the design, implementation and evaluation of the programme. Unavoidably,

85 Law 3304/2005 on the implementation of the principle of equal treatment, irrespective of race, nationality, religious or other beliefs, disability, age or sexual orientation, Official Government Gazette-ФEK issue A' 16/27-01-2005; Law 4443/2016, Official Government Gazette- $\Phi E K$ issue A' 232/o9-12-2016 for the explicit national integration of the Council Directive 2000/43/EC of 29 June 2000; Articles 2 and 3(1) of Directive 2000/43/EC.

86 Supra note 66, UN CRC Committee 2012, para. 17.

87 Article 1, Law 4025/2011, Official Government Gazette-ФEK issue A' 228/02-11-2011; Article 1, Ministerial Decision Y4a/OIK.122826, Official Government Gazette-ФEK issue B' 2674/og11-2011; European Commission, The Economic Adjustment Programme for Greece, Fourth Review-Spring 2011 (Brussels: European Commission, 2011).

88 Ministry of Labour and Social Security, National Strategy Framework for Roma, December 2011, pp. 8 and 22.

89 Ministry of Health, Ministerial Decision P2a/GPoik.27578/13-03-2012, paras. 2 and 4(II).

go Ibid., para. 3 . 
a large number of Roma run the risk of not having timely access to healthcare owed to structural factors, particularly the lack of the necessary health infrastructure (i.e., health personnel and healthcare facilities) in remote areas and less developed regions where they live, corresponding to $44.4 \%$ of Roma settlements. $^{91}$

Meanwhile, a promising development for the (cultural) acceptability and quality of healthcare services for Roma concerns the introduction of Roma mediation in Greece - albeit organized jointly by the CoE and the European Commission (ROMED)-. This development has the potential to facilitate Roma access to culturally-sensitive and quality healthcare by way of: (i) promoting communication between Roma communities and public (health) institutions; (ii) addressing Roma health needs; and (iii) highlighting gaps in Roma access to healthcare and obstacles that confront their ability to enjoy their right to health (care). ${ }^{92}$ Within this context Roma (health) mediation involves suitably trained individuals - Roma mediators - (i) with knowledge of Roma matters, such as language, culture (usually of Roma origin); and (ii) engaged in alerting Roma to the significance of health promotion, preventive care and vaccination by means of health-related campaigns organized in Roma communities. ${ }^{93}$ However, this seemingly well-intended project is still at a primary stage in Greece (i.e., for the period of 2011-2016, 108 mediators were trained, while 101 received an official ROMED certificate) and, thereby, its effectiveness and impact on Roma health status remains to be seen. ${ }^{94}$

In addition to the serious concerns raised with regard to the AAAQ, the question arises how the human rights principles of accountability and participation are given due attention when it comes to possible abuses against Roma in public healthcare settings. Accountability is conceptualized primarily through one independent authority, whose decisions, recommendations and reports are not legally binding, namely through the Greek Ombudsman and

91 Supra note 78, ECSR; supra note 66, UN CRC Committee 2012, para. 72(c); Supra note 66, Un CRC Committee 2002, para. 57(a); Supra note 63, UN CESCR 2015, paras. 35-36(b) and (d); For the census of Roma settlements in Greece, http://ekka-project.cpdev.crowd policy.com.

92 Supra note 20, paras. 35 and 46; Council of Europe Support Team of the Special Representative of the Secretary General for Roma Issues, ROMED leaflet 'Intercultural Mediation for Roma Communities' (a joint Council of Europe/European Commission action). Retrieved 26 April 2014, http://coe-romed.org/sites/default/files/leaflets/ ROMED1\%20-\%20ENGLISH.pdf; supra note 66, Council of Europe 2011, p. 19.

93 Ibid.; website of the CoE for Roma mediation, http://coe-romed.org/romed1, retrieved 20 February 2017; supra note 66.

94 See online at http://coe-romed.org/romed1/map, retrieved 20 February 2017. 
particularly its separate team for Roma issues. ${ }^{95}$ This authority is charged with conducting inquiries after receiving complaints by members of Roma communities; giving recommendations; preparing thematic reports on his/her own initiative; and publicizing matters to enhance Roma welfare. ${ }^{96}$ In 2014, on the basis of reported complaints the Greek Ombudsman concluded that despite the design of national Roma integration strategies, in practice there is a lack of correlation between state commitments and actions on the ground and as a result, a large number of Roma still encounter difficulties in gaining access to public services, such as public health services, combined with experiencing a high level of social exclusion in daily life. ${ }^{97}$ At the same time, according to recent survey data (2016), approximately none of the Roma respondents were aware of the existence of such accountability mechanism or a similar one, which might explain the low reporting rates among Roma for ethnic discrimination (8\%) against the high prevalence rates of such discrimination against Roma in Greece (48\%). ${ }^{98}$ Last but not least, the Greek state has not integrated Roma participation within its national processes in that there is an absence of systemic state responses to barriers to Roma access to regular and/or emergency healthcare, especially concerning for a large number of Roma predominantly living scattered in rural and remote areas of Greece, as aforementioned. ${ }^{99}$ Undoubtedly, past and current policy state health interventions were designed for the Roma rather than in consultation with them. ${ }^{100}$

\section{Conclusions}

Considering that the Roma in Europe are often exposed to poverty and highrisk living conditions and they are therefore vulnerable to increased health risks, access to substandard healthcare (or even a lack of access) is particularly disturbing from a human rights perspective. To remedy such abuses against the Roma and particularly, to address obstacles to their access to healthcare across

95 Law 2477/1997, as amended by PD 273/1999, Law 3094/2003 (Deputy Ombudsman for Children), Law 3293/2004 (Deputy Ombudsman for Health and Social Solidarity) and Law 3304/2005 (Deputy Ombudsman on Equal Treatment); Articles 101A and 103 para. 9 Constitution of Greece.

$96 \quad$ Ibid.

97 Greek Ombudsman, Special Report 2014: Combating Discrimination, pp. 118-119.

$98 \quad$ Supra note 15, pp. 40-41.

99 Supra note 66, UN CRC Committee 2012, para. 72(a); supra note 91; supra note 24, para. 54.

100 See, e.g., supra note 66, UN CRC Committee 2002, para. 81; supra note 66, UN CRC Committee 2012, para. 72(a). 
Europe (e.g., geographic segregation), states should shift the focus of their attention to the sustained inclusion of Roma health concerns and challenges both in their national budgetary and health policies. Therefore, by building upon existing legal standards this requires the development of a roadmap that entails measures to:

1. Ensure that an effective and a continuous monitoring system, based on evaluation mechanisms, primarily on the collection and analysis of data disaggregated by ethnic origin, gender and age, is in place. In essence, the analysis of such data will be of importance in order to detect health disparities between Roma and non-Roma groups; to discern the most pressing Roma health needs, especially of those living in rural and geographically isolated areas across Europe; to reveal any (potential) discrimination as regards to the actual level of healthcare provided to Roma across the several regions in Europe; and ultimately to enable the effective implementation of legal standards in practice.

2. Advocate and ensure effective Roma participation in the design, implementation and evaluation of health programmes and interventions, by means of regular consultations with their representatives and research evidence that document their views and needs.

3. Enforce accountability mechanisms to systematically monitor reports of Roma abuse in healthcare settings. In this regard, as an additional step it is recommended to also invest in raising awareness among Roma on their right to access justice and to seek appropriate remedies for infringements of their right to health (care).

Without such energetic steps to institute considerable changes, Roma access to appropriate healthcare in Europe will remain an empty promise and a major challenge for states. Undoubtedly, when a state is confronted with resource constraints, the right to health (care) of vulnerable population groups, like Roma in this case (i.e., in resource-poor settings), comes under serious pressure. When looking the case of Greece, the formulation and implementation of sustainable health interventions targeted to the needs of Roma living across its several regions, and especially in remote and less developed regions, will remain subject to resource availability and more crucially, upon efficient use and prioritization of existing (limited) resources, given the economic recession rooted in the country since 2010 . Nonetheless, it must be conceded that economic pressure does not absolve a state from its legal obligations under the right to health. On the contrary, a non-affluent state such as Greece must abide by its obligations within the context of its fiscal policy by setting concrete 
priorities to mitigate the impact of the austerity measures taken as regards to vulnerable groups like the Roma. Otherwise, its failure will implicate a lack of political will, and consequently, a (potential) violation of its legal obligations. Nevertheless, despite the several weaknesses of the implementation process in the case of Greece (e.g., ineffective policies), we can discern some promising practices (i.e., health mediation), which have the potential to enhance Roma access to healthcare if taken seriously, namely, if effectively implemented (e.g., allocation of the human, financial and technical resources required). 